Waste Waters : Their Nature and Disposal", which has long been the authoritative work on this subject. It was while he was with the Rivers Board that Calvert was awarded in 1915 the D.Sc. degree of Leeds.

In 1920 Calvert moved to London to take up a new appointment as chemical inspector of the Ministry of Health, a post which gave him wide scope and in which he was eminently successful. When in 1927 the Department of Scientific and Industrial Research set up a water pollution research organisation, Calvert was the obvious choice as director of research, and he undertook this responsibility in addition to continuing his work for the Ministry of Health. $\mathrm{He}$ did not believe in rapidly developed schemes of a grandiose character, but in steadily building up on a sure foundation. This policy he followed in guiding the work of the Water Pollution Research Board in excellent partnership with every member of the Board, which was under the chairmanship of Sir Robert Robertson. By 1939, the research organisation had several outstanding achievements to its credit, including a comprehensive survey of the River Tees, an investigation into the effects of discharges of sewage into the River Mersey in relation to problems of navigation, improvements in methods of treatment of sewage, and the development of practicable methods of dealing with the problems of reducing pollution by such trade waste waters as those from beet sugar factories, milk depots, cheese and butter factories, to mention only a few items.

Calvert was recognized as an authority in his field not only in Great Britain, but also throughout the world; and he had close friendship with many professional colleagues on the Continent and in the United States. In addition to his many papers and addresses in Great Britain, including a Chadwick Public Lecture in 1926, he accepted an invitation in 1939 to give the Sedgwick Lecture in the following year at the Massachusetts Institute of Technology, but unfortunately was prevented by the outbreak of war from delivering the lecture. In 1944 he received the Kenneth Allen Award of the American Federation of Sewage Works Associations.

He took a keen interest in the work of the Institute of Sewage Purification, of which he was president in 1927, 1928 and 1939, and was a member of the Council of the Institute for many years. Calvert was also a prominent fellow of the Royal Sanitary Institute, and the Institution of Sanitary Engineers, a professional associate of the Institution of Water Engineers, a member of the Society of Chemical Industry, and a fellow of the Royal Institute of Chemistry and of the Chemical Society.

During the First World War, from 1916 until 1919, he was with the Department of Explosives Supply of the Ministry of Munitions, and his work was recognized by the award of the M.B.E. On the outbreak of war in 1939 he was seconded to the Ministry of Supply as deputy controller of sulphuric acid, which post he retained until his retirement early in 1947.

Calvert was a man of kind heart and generous disposition, with a markod ability in quiotly getting boards, committees and staff working together amicably and efficiently, and all who worked with him came to know him as a close friend. $\mathrm{He}$ wais devoted to his family. The death of his wife in 1937 was a severe blow to him. All three of his sons have had distinguished university careers, one in physics, a second in chemistry and engineering, and a third in arts and law.
Surgeon Rear-Admiral C. M. Beadnell, C.B.

Surgeon Rear-Admiral Charles Marsh BeadNELL, who died at Petersfield, Hampshire, on September 27, was president of the Rationalist Press Association, Ltd., and the author of several scientific books. Born at Rawalpindi in 1872, he was educated at Cheltenham College; and after studying medicine at Guy's Hospital he joined the Navy as a surgeon in 1896. He came to intellectual maturity while the great evolution controversy was still raging, and fell under the spell of Huxley. He became an ardent rationalist, and although service conditions somewhat restricted the propagation of his views, he frequently contrived to give lectures on evolution to the 'lower deck'. On one occasion the commander-in-chief attended, and instead of administering the expected rebuke, he merely remarked that he had enjoyed the lecture very much; but, he added: "On second thoughts, Adam and Eve are good enough for me".

Beadnell's enthusiasm for science led him to buy, out of his own earnings, an X-ray apparatus, the first to be used in the Royal Navy. In the AmericanFilipino War he collected specimens of bullet injuries to skulls, when he found that the Filipinos did not bury their dead. During the Boer War, when pronounced medically unfit for front-line service he broke away from a hospital train and tramped all night to take part in the fighting at Graspan. The Titanic disaster stimulated him to invent an airdistensible waistcoat.

In 1922 Beadnell represented the Navy and Army Medical Departments at the International Congress of Surgeons at Washington. On his return he became head of Chatham Hospital, retiring at his own request four years later. Retirement brought him the opportunity to devote much of his time, and his gift for simple exposition, to general science and the cause of rationalism. The fire kindled in the great days of Huxley never died; but perhaps the strongest influence was that of W. K. Clifford. His intelloctual integrity was as unquestionable as his physical courage, but he was no fanatic. In a revealing letter, written the day before he died, he declared that Clifford had brought him from "the respectable sphere of Agnosticism to that of Atheism ; not of the blatant type, but of a convinced, quiet kind in which I would not argue in public on religious questions, if other officers I knew to be religiously porsuaded happened to be present". He became a director of the Rationalist Press Association and succeeded Lord Snell as president in 1940. Among his publications were: "Evolution of Speech", "Picture Book of Evolution (after Donnis Hird)", "Origin of the Kiss", "Dictionary of Scientific Terms" and "An Encyclopædic Dictionary of Science and War".

\section{Prof. Paul Guthnick}

Prof. Paul Guthnick was born at Hitdorf am Rhein on January 12, 1879. After studying under Küstner at Bonn, he became an assistant at the Berlin Observatory in 1901. After three years at the Bothkamp Observatory, he returned to Berlin in 1906 and moved steadily up in the scale of Observa. tory and University posts until 1921, when he succeeded Hermann Struve as professor of astronomy in the University of Berlin and director of the University Observatory at Berlin-Babelsberg. In 1927 he was elected an associate of the Royal Astronomical Society. 